\title{
The role of oversight in foreign-national only prisons: counteracting the disapplication of rehabilitation
}

\author{
Róisín Mulgrew ${ }^{1}$
}

Published online: 14 December 2017

(C) The Author(s) 2017. This article is an open access publication

\begin{abstract}
In several European countries, prisons have been created solely to house foreign national prisoners without leave to remain. Contrary to contemporary international human rights law and standards on prison management, there seems to be a trend towards the disapplication of rehabilitative theory and practice for this group of prisoners. In particular, they do not seem to receive the same preparation for release and reintegrative support as other prisoners. This paper explores the role international standards and oversight bodies have in upholding rehabilitation as the foundational objective for prison management in foreign national only prisons. It outlines the changes to the prison estate, policy and regime that have resulted from the increasing focus on removal within both the prison and penal process. The consequences of the disapplication of rehabilitation for prisons, prison officers, prisoners and society itself are analysed before the paper moves to examine the role oversight bodies could and should play in the protection of the rights of this vulnerable category of prisoner and the primacy that should be accorded to rehabilitative theory and practice. It concludes by asking whether such standards and oversight have inverted the panopticon by placing the trigger for international reactions in the hands of prisoners and NGOs.
\end{abstract}

\section{Introduction}

Foreign national prisoners represent a significant, if not a majority, percentage of the national prison populations of most Western European countries. For this reason, Ugelvik argues that rather than being forgotten, this group of prisoners has become a priority consideration for governments and prison administrations [1]. This prioritisation has been demonstrated by the creation of facilities to house only (male) foreign prisoners who do not have (or have lost) the right to remain in Norway, the Netherlands and the UK. Such facilities provide a fitting lens with which to view the

Róisín Mulgrew

Roisin.mulgrew@nottingham.ac.uk

1 School of Law, University of Nottingham, University Park, NG7 2RD Nottingham, England 
issues raised in this Special issue, as Kaufman has argued that they establish a panoptic model for the management and administration of foreign national prisoners.

Based on academic scholarship, oversight reports and data gathered during empirical research conducted at two of the four facilities discussed (Ter Apel prison and Kongsvinger prison (details on file with the author)), this paper explores the role international standards and oversight bodies have in upholding rehabilitation as the foundational objective for prison management in foreign national only prisons. It outlines the changes to the prison estate, policy and regime that have resulted from the immigration focus of prisons and penal process, focusing, in particular, on the disapplication of rehabilitation. The consequences of these changes for local institutions, prison officers, prisoners and society itself are analysed before the paper moves to examine the role oversight bodies could and should play in the protection of the rights of this vulnerable category of prisoner and the primacy that should be accorded to rehabilitative theory and practice. It concludes by asking whether such standards and oversight have inverted the panopticon by placing the trigger for international reactions in the hands of prisoners and NGOs.

\section{The emergence of prisons for foreign nationals without leave to remain}

The media and politicians in Europe 'routinely propagate an alarmist discourse ... depicting [foreigners] as dangerous and deviant' ([2], 184). Wacquant argues that labelling of foreigners as 'inherently criminal property' has justified the implementation of an aggravated retributive approach which punishes foreign offenders for both the crimes they commit and who they are [3]. Politically created populist fears about foreigners have translated into concrete penal policies and practices and the emergence of what Fekete and Webber call 'enemy penology' ([4], 6). The 'moral panic over outsiders' ([2] at 185) has created a situation whereby there is political currency to be gained from removing this 'threat' to society and national security $[5,6]$. National legislation often results in the automatic removal of non-European nationals convicted of criminal offences and allows for the discretionary removal of Europeans with criminal convictions if they pose a threat to public order or national security. Recently, the mandatory process for the removal of nonEuropean offenders has become activated by convictions for less serious crimes and following the imposition of shorter sentences [7]. As Hasselberg notes 'deportation complies with public expectations and electoral politics, it assures the voting public that the problem has been identified and is being addressed by state authorities' ([8] at 565). New penology therefore focuses on the control and expulsion of categories of persons through punishment $[5,9]$.

In addition to legislation that facilitates removal, there has been a movement towards structuring prison estates around 'the issue of foreignness' [10] and the containment of (what is perceived to be) a dangerous and threatening category of offenders that should be removed from society [11]. Many European States concentrate foreign national prisoners in specific prisons or in particular wings within prisons [1]. Another level of differentiation, however, has occurred due to the re-structuring of national penal estates on the basis of residency rights. This re-structuring was primarily based on political objectives to prevent the release, and facilitate the deportation of, non-resident foreign prisoners at the end of their sentence. Within Europe, the UK, Norway and the 
Netherlands have designated particular facilities to exclusively house prisoners that do not have, have lost or are likely to lose the right to remain in the country.

The UK system is based on the 2009 Agreement between the National Offender Management Service (NOMS) and the UK Border Agency (Hubs and Spokes) which resulted in foreign offenders being moved to prison facilities in which border control officials are based. This Agreement was put in place after the political fallout and media backlash that followed revelations in the 2006 National Audit Office report that over 1000 illegal immigrants had been released back into society rather than deported in the previous 7 years [12]. While foreign prisoners remain dispersed throughout the prison estate, two prisons have been designated to house foreign nationals only: both HMP Maidstone and HMP Huntercombe became designated foreign national prisons and Home Office Immigration Enforcement Centres in 2013.

In the Netherlands, Ter Apel Prison was designated as 'the' national facility to house male prisoners without leave to remain in 2013. In October 2015, this represented 647 of the 1916 foreign prisoners in the country. The political objective for centralising these prisoners was to facilitate cooperation between the criminal justice system and the immigration system, and thereby increase the effectiveness of deportation procedures. This was based on political pressure to avoid the repeat of the situation whereby irregular migrants convicted of crimes had been released back into society.

In Norway in 2010, the police drew attention to the fact that they arrested more foreign nationals than Norwegians in Oslo and that foreigners represented $70 \%$ of the population in Oslo Prison [1]. Politicians were also keen to find a way to keep foreign prisoners who were going to be deported out of expensive rehabilitation programmes and the prisons that ran them. Following a Ministerial Letter in 2012, Kongsvinger Prison transitioned to a facility to house foreign prisoners facing expulsion or transfer to another country within 1 or 2 years.

The concentration of this specific category of prisoner in designated facilities may be seen as beneficial in a number of regards. The prisoners are housed with people in a similar situation (facing deportation). Accordingly, they can foresee what will happen more clearly and have access to individually directed sentences if they do not wish to remain. Many of these prisoners are eager to return to their own countries and indeed often leave voluntarily. They can access specialist information about immigration and support available to them upon release. Separation also prevents foreign prisoners becoming frustrated by national prisoners' entitlements to leave, better educational rights, opportunities to work outside prison and progression to lower security facilities. From a prison management perspective, staff can become specialised in dealing with the needs of this specific group, both in terms of day-to-day life and the paperwork involved. Better and more focused resources are made available - for example, for instantaneous interpretation.

Despite these benefits, however, it cannot be ignored that the political decision to establish these specialist institutions has heralded in 'a significant new role for the prison, binding it to border control and in the process, altering its purpose and effect' ([7] at 126). The recent re-structuring of the prison estate around residency rights in the UK, the Netherlands and Norway has created what Kaufman describes as a panoptic model of prison management that enables the exercise of border control within the prison ([12] at 7). Imprisonment has therefore become 'a principle organising dynamic in a cluster of "technologies of exile" which are embedded in an approach that seeks to immobilise, exclude or eject' ([2] at 191). Increasing evidence is emerging which 
shows that these foreign national only prisons are becoming 'places of exclusion and immigration control rather than reform' ([13] at 15).

\section{Rehabilitation and reintegration in foreign national only prisons}

While the creation of this type of facility is a relatively recent phenomenon, the governments remain bound by the same treaty law requirements and soft law recommendations relevant to the operation of prisons. There is a clear consensus in international treaty law (Article 10(3) 1966 International Covenant of Civil and Political Rights) and soft law (Rule 9 Council of Europe 2012 Recommendation concerning foreign prisoners (2012 Rec); Rule 6 Council of Europe 2006 European Prison Rules (EPR)) that the fundamental premise and ultimate objective governing the management of prisons is the rehabilitation of prisoners. The term 'rehabilitation' is to be understood for the purposes of this paper as a broad concept which includes addressing the crime committed; assistance with improving vocational and educational skills; progression to lower security settings; and steps to assist an offender to reintegrate into society upon release. Worryingly, studies have shown that that this goal has been subordinated due to the removal focus in foreign national only prisons.

\section{Rehabilitation}

Rehabilitative theory can be operationalised in a number of ways, including through the provision of purposeful activity, education, training, access to work and progression to less restrictive regimes.

\section{Activities}

The 2012 Recommendation advocates equal access to a balanced programme of activities for foreign prisoners, and expressly states that such access should not be restricted because a prisoner may be facing expulsion (Rule 26.1-2). While efforts were being made at the local level to provide the best possible programme of activities within the budget provided, it was clear that this was not always the same standard as the regime provided in other prisons. For example, at Ter Apel prison, there was no evening programme of activities or possibilities for weekend visits. Kongsvinger prison provides a range of education and employment activities, but was criticised for the lack of time prisoners spent outside of their cells and warned that the lack of activities could have 'negative consequences for the health and welfare of inmates' ([14] at 17). The UK facilities on the other hand seemed to be providing a sufficient or good level of purposeful activities and time out of cell ([15] at 5; [16] at 5, 14). However, other research has noted that the transition of prisons in the UK to special foreign national prisons resulted in usual practice being 'subsumed under the interests of immigration' with the consequence that prisoners were finding it 'immensely difficult to access a range of prison programmes' ([12] at 9). The reduction in activities is problematic given that these facilities often house prisoners with long sentences: $60 \%$ of prisoners in Maidstone prison are serving over 4 years ([15], Appendix III at 73), while at Ter Apel prison some prisoners are serving sentences of between 10 and 25 years. The 
resulting monotony of a limited regime makes it difficult for prisoners to deal with their prison term, particularly given that they face removal at the end of this period.

\section{Education and training}

The 2012 Recommendation notes that educational and vocational training could include working towards qualifications recognised, and that may be continued in, the country to which the prisoner will be released (Rule 29.2). At Kongsvinger prison, education and training provision was altered to ensure it was suitable and useful for prisoners who will be returned to another country - focusing on languages, skills and qualifications that could be used post-release. However, this is not always the case. In Ter Apel prison for example, the education and skill training provision was described by staff as very basic and not suitable for preventing a return to criminality. In Maidstone prison, the range of education provision was found to be limited, the quality of teaching was variable and there was a lack of employment ([15] at 5). This can be contrasted with Huntercombe prison, where a very good breadth and quality of accredited education, work and training programmes were on offer ([17] at 5, 14).

\section{Offending behaviour programmes}

There is also growing evidence that prisoners in such facilities have very limited or indeed no access to offending behaviour programmes ([12] at 9,12). This means that the criminality of this category of prisoner is not being addressed. Inspections found that there were no offending behaviour courses at Kongsvinger prison ([14] at 15) and no reducing offending strategy at Maidstone prison ([15] at 15, 49). Huntercombe prison had no accredited offending behaviour programmes and the non-accredited programmes had very long-waiting lists ([16] at 16). This resulted in the reality that many prisoners, including sex offenders, were likely to be deported without completing suitable programmes $(15,49,53)$.

\section{Progression}

Another notable feature of this method of structuring the penal estate is that normal principles and procedures of progression are typically not applied to foreign national offenders without leave to remain. Contrary to penal standards, which warn against using generalised risk assumptions, such prisoners are typically viewed as presenting a high risk of absconding. Accordingly, they are rarely granted temporary release, moved to lower security or more open facilities, or allowed to work outside (see [15] at 15-6, 50-2). As Ugelvik notes, foreign national prisoners 'are frequently denied the ladder of progression designed to aid them in their rehabilitation process' ([1] at 116). This creates frustration among prisoners who feel they are being denied access to 'less restrictive conditions even though they [are] advancing through their sentences' ([18] at 6).

\section{Reintegration}

The prison regime should prepare prisoners for their social reintegration after release (Rules 9, 35.12012 Rec; Rule 6 EPR; Rules 4.1, 91 UN Standard 
Minimum Rules (Mandela Rules)). Planning for resettlement should begin upon the prisoner's arrival and 'underpin the work of the whole prison' ([15] at 49). In stark contrast to this principled approach, the reality in most removal-focused prisons is that the resettlement function has been eroded to the extent that prisoners do not receive the advice necessary to prepare for release or their social reintegration into society ([12] at 12). Slade notes that 'while effort and resources are increasingly focused on the process of expulsion, there is an extraordinarily casual attitude to the resettlement and reintegration of foreign prisoners' (16). While there is evidence of effort and some successful attempts to adjust to this new role ([16] at $12,14-5,47,51)$, most evidence suggests that this is a major failing in foreign national only prisons. For example, HMIP strongly criticised Maidstone prison in this regard, stating that the role of resettlement was unclear and that there was no central or local strategy for the management of resettlement or coordination of relevant services ([19] at 5, 15, 17 and 49). Moreover, there was simply no resettlement needs analysis for the population in question. These strategic problems were compounded by the lack of completed offender assessments, sentence plans and offending behaviour courses, late status decisions and poor levels of contact between prisoners and offender supervisors. The outcome was that prisoners 'were routinely deported or released into the UK without their offending behaviour and resettlement needs being addressed' ([15] at 15-17, 49, 51). More bluntly, the prison simply 'did not address the resettlement needs of prisoners who were removed from the UK' (15). The significance of these failings becomes clearer when it is revealed that $90 \%$ of inmates are discharged directly to their country of origin (5). Despite the overall praise for the work in relation to resettlement and reintegration at Huntercombe prison, HMIP noted that 'as is often the case with a foreign national population, more could have been done to meet the needs of those due to be deported' (12) and recommended that the strategy take account of the specific resettlement needs of prisoners being removed from the UK $(48,59)$.

The ability of both the prison and the prisoners to plan for release is also detrimentally affected by the length of time it takes for status decisions to be made and become final. While the 2012 Recommendation encourages States to ensure status decisions are taken as soon as possible (Rule 35.2b) they are often not reached until the very end of the sentence (or afterwards). The resulting uncertainty about not just when, but if, the person will be removed and to which country, has a foreseeably frustrating effect on any attempt to make arrangements for the future.

Conclusion From a human rights and penological perspective, the core objective of prison management should be the facilitation of the rehabilitation and reintegration of prisoners. This is particularly true in facilities where approximately $75 \%$ of the population are under 40 years of age ([15], Appendix III at 73; [16], Appendix II at 65). This clarity of purpose, however, seems to have become skewed and subordinated within foreign national only prisons: inspections, empirical studies and academic scholarship all point to the 'erosion of the rehabilitative ideal' ([18] at 3 ). 


\section{Differentiated content: A slippery slope towards the disapplication of rehabilitation}

The structuring of prison estates on the basis of residency rights has resulted in the subordination, if not the disapplication, of rehabilitative theory and practice for prisoners facing (potential) removal. Politically, this is explained by the need to provide 'differentiated content' for prisoners that will not be reintegrated into the detaining State's society.

\section{Localised adaptation of content without strategy or support}

When asked to describe the objectives behind the establishment of a prison for foreign nationals without leave to remain, the Director of the Norwegian Prison Service explained that 'the aim is to ensure standards are not less. Kongsvinger is not a ' $\mathrm{B}$ ' prison'. But it does provide a different content' (Interview, 5 October 2015). The S'OM inspection of Kongsvinger prison revealed that the prison's activity programme had been re-organised on the basis that 'the population would not resume life in Norway and accordingly should serve their sentence under "specially adapted conditions" ([14] at 15 ). However, it seems that foreign national only prisons have received virtually no guidance from central authorities about what 'different content' or 'specially adapted conditions' should look like in practice.

Both the Dutch and the Norwegian prisons noted that they received no guidelines from the central authorities about how to adapt content for the new target group. Accordingly, this adaptation had to be designed at the local level. National prison law and policy does not set out a regime applicable to foreign prisoners without leave to remain. This creates difficulties in a context where the 'complexity of [their] carceral experiences and resettlement needs' are often poorly met by national structures and procedures ([12] at 7). Normal rights and privileges are often disapplied for this category. The lack of clarity on which rights do and do not apply and the lack of an explicitly tailored regime make it very difficult to operate a facility that only houses this population of prisoner.

What the prisons did receive, however, was a reduction in or removal of the budget for rehabilitation-orientated components of the prison programme. For example, the HMIP report on Maidstone prison notes that despite the fact that $90 \%$ of the prisoners are released directly from the facility, it had not been designated as a resettlement establishment and therefore did not have resources allocated to it for this purpose $(2015$ at $5,16,49)$. In fact, funding for resettlement work had been withdrawn in line with the national 'Transforming Rehabilitation' approach (53). Requests for finances from Ter Apel prison to launch initiatives were frequently denied by central authorities as the prison was 'the last priority for costs due to the official perception that it does not bring society any benefits' (Interview, Deputy Governor, 26 October 2015). Worryingly, the Governor at Kongsvinger prison noted that there had been political pressure during the run-up to a recent election to reduce the budget below the level needed to ensure equal standards with other Norwegian prisons (Interview, 6 October 2015).

The vacuum left by the state withdrawal of support for reintegration programmes has been partially filled in some instances by external bodies: the Peer Advisor scheme run by St Giles Trust at HMP Huntercombe; the Safe Way Home programme operated by the Salvation Army in Norway; the placement of an International Organization for 
Migration office in Ter Apel Prison. This work by NGOs and religious institutions, does not, however, negate the fact that States are failing in their resposibility to provide rehabiliiative or reintegrative support to many foreign prisoners facing deportation. While there may be some merit in exploring the possibility of sharing the burden of reintegration support costs with the receiving State ([20] at 173), this does not dispel the country's responsibility to uphold treaty imperatives and penological standards. Yet, contemporary practice seems to support the perception among staff and management at Kongsvinger prison that once the prison transitioned to its new role, and was 'ticked off the political to-do list', interest and resources stopped.

\section{The impact of the prioritisation of removal}

The creation of foreign national prisons designed to facilitate deportation has formalised a state-sanctioned 'confinement of differentiation' - detention that prevents integration with and facilitates subtraction from society ([3] at 91). The focus on ensuring efficient returns overshadows and subsumes normal penal policies and practices. With the focus being on removal from the prisoner's first day in prison ([10] at 701), the reality is that 'concern for reintegration [has been] subordinated to expulsion' ([21] at 35). For example, the UK's National Offender Management Service admitted that while the role of a foreign national only prison was initially the same as for other prisons (reduce risk and assist with reintegration), it acknowledged that at the point a deportation notice was served - the facilitation of removal also became an objective ([15] at 49). In practice, it seems the latter has (almost completely) overridden the former: as the HMIP report stated, 'sentence planning, offending behavior and resettlement needs did not lead the sentence for most prisoners' (16).

There has been a reduction in efforts to prevent deterioration with a varied regime or to provide meaningful opportunities and assistance with resettlement. Moreover, decisions to reduce or withdraw support are deliberate, publicly stated and popular. Residents are to receive support and motivation to reintegrate whereas non-residents are to be motivated to return to their own country. Rather than treating the penal and immigration processes as distinct - the establishment and operation of removal-focused prisons has enabled the prioritisation of a politically driven end result (deportation) over the treaty and regulatory foundation for penal process (rehabilitation). In practice, foreign national only prisons are increasingly operating without penal purpose and morphing into pre-removal holding centres.

\section{Consequences of the disapplication of rehabilitation}

The removal focus has resulted in the acceptance and promotion of a bare penality and the operation of a system that has punitive effect but lacks any penological justification. This new reality has had serious implications for prisons, prisoners and society.

\section{Significant change in the prison officer's role}

The altered purpose of foreign offender only facilities has resulted in significant and unwelcome changes to the prison officer's role. Due to a lack of information about and involvement in the immigration process, or resources and training to provide 
meaningful support to prisoners, they are no longer able to fulfil one of the core aspects of their job - the provision of assistance with rehabilitation and resettlement.

Prison officials are well aware that 'foreign nationals are increasingly being seen more like potential deportees than potentially rehabilitated members of society: as risks to be managed and expelled, rather than individuals with individual needs' ([1] at 113). Rather than prepare prisoners for life in society, staff are often restricted to persuading prisoners to cooperate with immigration authorities by getting on the plane to go 'home' (and not to come back).

This limited role had negatively impacted on morale and resulted in some staff becoming less involved with prisoners ([14] at 21; [15] at 13). This reduction in interaction has resulted in a greater focus on static security issues. This development is contrary to the EPR requirement that 'the duties of staff go beyond those required of mere guards and shall take account of the need to facilitate the reintegration of prisoners into society (Rule 72.3) (emphasis added). Staff can no longer 'manifest a clear sense of purpose of the prison system' (Rule 72.2 EPR).

The de-professionalisation of the prison officer role is further compounded by the failure of central authorities to provide tailored training on the needs of the new target population in such facilities despite the interest of staff in receiving it ([15] at 13; [16] at 12) and international standards insisting that it be provided (see Rules 12, 39.2, $39.52012 \mathrm{Rec}$; Rule 81.3 EPR; Rules 75.2, 76.2 Mandela Rules). Therefore, despite the claim that the creation of such facilities would result in the specialisation of staff in dealing with this category of prisoners, what has happened in practice is specialisation in facilitating efficient deportations.

\section{Specific pains of imprisonment}

A distinction can be made between two different sub-categories of foreign prisoners without leave to remain: those that come to a country to commit a crime and residents who lose their legal status when they commit a crime. The former category often wish to leave as soon as possible and return to their home country. However, for the latter category, the lose of legal status and pending deportation can be very difficult to accept as it will mean leaving their home and families and 'returning' to a country that they have not lived in for a long time, or indeed ever. For these prisoners, 'their inability to plan for a future, their insecurity where and when their release may come, their lack of access to the rehabilitative and resettlement processes' can result in the loss of hope ([12] at 12-3). This is particularly the case when their removal will have a serious and life-shattering impact 'undoing long histories of habitation, familial relations and livelihoods' ([18] at 2). The stress of such uncertainty (and likely separation from their loved ones) has been shown to result in a higher risk of self-harm and suicidal feelings [4, 10, 22]. In fact, Warr has argued that the 'lack of certitude, legitimacy and hope with regard to both their carceral and postcarceral lives' ([12] at 2) experienced by foreign prisoners facing removal has resulted in new and unique pains of imprisonment for this specific category of prisoner.

\section{Public safety}

As discussed above, prisoners from these facilities are often released back into society without their criminality being addressed or any support structures being put in place to 
prevent recidivism. Not all prisoners however are released in another country: approximately $10 \%$ of their population are released back into the detaining State's society on account of late grants of asylum or leave to remain, a failure to secure documents for individuals or human rights concerns about the situation in the proposed receiving State. Therefore the lack of a rehabilitative focus has direct consequences for the safety of society in the detaining State. Further, these facilities have witnessed a high rate of persistent returns and re-offending by ex-prisoners.

Slade's warning that returning prisoners to their home countries without support or intervention is 'desperately irresponsible' ([13] at 28) seems to be borne out by the level of repeat returns and the involvement of such offenders in organised cross-border crime [20]. For example, at Kongsvinger prison it was normal to see the return of prisoners (usually those convicted of economic smuggling offences) that had been imprisoned and deported 7, 8, even 10 times previously. As a Swedish Prison Director noted; 'we can't just lock them up without giving them anything and think that they will never come back. They are already back' ([13] at 16).

\section{Prison estate capacity}

The level of repeat returns and re-offending also has implications for the capacity of the prison estate. Deportation orders increasingly contain a ban on return, breach of which results in any old sentence being re-activated and an additional term of imprisonment. So not only are these facilities failing to assist with reintegration or prevent the return of such prisoners, these individuals end up back in the facility serving another sentence or a sentence imposed for a breach of the condition not to return. In Norway in 2015, for example, nearly 140 individuals were sentenced to a term of imprisonment for breaching the ban on return - which is more than the capacity of Kongsvinger prison.

Conclusion Contemporary practice in foreign national only prisons often fails to uphold human rights standards or achieve penological goals as it focuses on the treatment of categories of persons as defined by their residency rights rather than their reintegrative needs. The view that different services and regimes are required as the target group "is not going to be reintegrated" is misplaced: such prisoners will have to be reintegrated into $a$ society - it may simply be a different one.

\section{The role of oversight bodies in upholding the fundamental objective of penal management}

Foreign prisoners' rights are being eroded by their re-categorisation as national welfaresystem entitlements dependent on residency status (see [14] at 16 (fn 22)). Following this logic, it has been argued that rehabilitation support is not necessary for foreign prisoners as they will not be reintegrated into that particular society ([20] at 165; [1]). Yet, this differentiated treatment has no basis in international law or policy, and despite its political and populist acceptance and advocacy, risks being discriminatory. The Mandela Rules explicitly forbid discriminatory treatment of prisoners on the basis of national origin or any other status (Rule 2.1). A recent HMIP report also draws 
attention to the fact that prisons and central authorities should address the resettlement needs of prisoners, 'irrespective of their immigration status' ([15] at 53, 61). While it is accepted that the detail of implementation may change, the duty for state authorities does not. Despite this, contemporary practice in relation to foreign offenders often 'flies in the face of modern penal policy, which holds that punishment should be tailored to the individual, should fit the crime and should be geared towards the rehabilitation of the offender' ([4] at 3). This section explores the role of oversight bodies in countering the disapplication of rehabilitation.

\section{Prisoner protest?}

Foreign national offenders facing removal are less likely to engage in public or collective political protest due to the perceived futility of doing so in light of government priorities and a lack of public sympathy [8]. There remains, however, evidence of individual acts of 'resistance and contestation' ([8] at 568) from within the prison through the destruction of documentation, self-harm, suicide and hunger-strikes.

Foreign national only prisons have been described (both internally and independently ([14] at 36; [15] at 11,$13 ;[16]$ at 5,12$)$ ) as calm and relatively safe environments with very few incidents (either between staff and prisoners or between prisoners). They report virtually no issues with radicalisation, organised crime, gang culture or drug use. There is, however, evidence of acts of resistance by prisoners.

There have been reports of increased self-harm and suicide attempts being used as a form of protest by foreign national prisoners in the UK ([13] at 7-8).

At Ter Apel prison, the rate of hunger-strikes is much higher than at other Dutch prisons. They occur regularly (every 2-3 weeks), and some last for a long time. Management and staff are unsure if this is because of the cultural background of the prisoners or if a culture of using hunger-strike as a means to get things is developing in the institution. There is, however, recognition that hunger strikes are being deployed as an act of desperation by those who have lived in the country for a long time and are facing removal as they feel they have no other means to protest. Desperation also caused one prisoner to sew his mouth shut to demonstrate that he had no voice.

While hunger strikes are not prevalent at Kongsvinger prison, escapes are. Between the 1 June 2013 and 7 October 2015, 35 persons escaped from this facility (didn't return from work, activity or leave). The escapes were prompted by a wish to avoid deportation and facilitated by their placement in a low security facility. While some escapees were recaptured, the ensuing political uproar meant that the prison could no longer bring prisoners outside for cultural events or work.

\section{Independent oversight}

Given the prisoners' perception that they have no voice, and with little NGO advocacy to promote better conditions of imprisonment, independent oversight is extremely important to ensure that the rights of foreign prisoners without leave to remain are protected. According to the Mandela Rules, the purpose of inspections should be twofold - to protect the rights of prisoners and to ensure that the prison is being managed in line with legal and policy requirements in a manner that 'brings 
about the objectives of penal and correctional services' (Rule 83.2). To understand how the mandate and methodologies of different inspectorates can impact upon the role oversight bodies can play in upholding fundamental penal objectives, this section analyses the inspections of foreign national only prisons by two national preventative mechanisms (NPMs) that operate pursuant to their State's obligations under the UN Optional Protocol to the Convention Against Torture: Her Majesty's Inspectorate of Prisons, UK (HMIP) and the Parliamentary Ombudsman, Norway (S'OM). The Dutch NPM has not conducted a review of Ter Apel prison to date.

\section{Methods and mandate}

The S'OM report concluded that Kongsvinger prison had attended 'to its role as a unit for foreign inmates in a satisfactory manner' ([14] at 3, 31). However this seems to be based on the prisoners' perception that it was a safe institution free from violence, harassment, abuse or discrimination from staff or other prisoners. In contrast, the HMIP report noted that while Maidstone prison was a 'reasonably decent place where people were treated respectfully', the prison was unsure of its role and that it needed to address serious shortcomings in relation to reducing the risk of re-offending and preparing prisoners for a return to the community (2015 at 5-6). HMIP inspections are based on the analysis on four tests of a healthy prison - safety, respect, purposeful activity and resettlement. Resettlement is discussed in relation to several components including the strategic management of resettlement, offender management and reintegration planning.

The S'OM report does not discuss rehabilitation or reintegration as distinct heads of assessment. If S'OM had used the same heads of assessment as HMIP, it may not have reached the same conclusion. Indeed, its finding seems to be at odds with some of the issues raised by the S'OM report itself. For example, the report discussed the lack of offending behaviour courses, lack of access to post-primary education and training and reduced interaction between contact officers and prisoners. Though important rehabilitation-related issues were raised, they were simply stated without further comment and no recommendation was made for remedying the situation. This approach contrasts with the approach adopted in relation to other issues raised in the report, where clear recommendations were made. It also contrasts with the HMIP model, where explicit recommendations stating the remedial actions required (in order of priority) and the responsible body/bodies are set out in both the report and a supplementary action plan.

The variation in the approaches of the two NPMs can be attributed to the different mandates of these bodies. The broader scope of enquiry adopted by HMIP is due to the fact that it pre-existed OPCAT: its NPM role is only one of its functions as an inspectorate. Accordingly, it has a wider remit and adopts a more strategic approach to its analysis of operations. The S'OM NPM, on the other hand, was created precisely to fulfil Norway's OPCAT obligations. Consequently, its mandate is narrower and its analysis is more rights-protection based. Its prevention of torture focus is evident in its pre-visit inquiries and the report's recommendations (use of security cells and restraint beds, access to psychological and psychiatric treatment, confidentiality in medical care etc). Further, the S'OM report referred to a broad range of international and regional treaty law, jurisprudence and penological standards, whereas HMIP reports do not. 


\section{The ability of oversight mechanisms to affect change}

Given the prisoners' perception that they lack a voice, independent oversight, based on international standards, is critical for the protection of prisoners' rights. However, the ability of monitoring bodies to fulfil the other Mandela Rules' requirement (to ensure the attainment of penological objectives) may be constrained by their particular mandate and methodology. Where clear recommendations for change are made, it seems that institutions and authorities are open to discussion and meaningful dialogue ensues.

Looking at the reaction to HMIP's critical report on Maidstone prison, for example, it is clear that the central authorities and prison accepted the vast majority of findings and recommendations. While the main recommendation in relation to resettlement has not yet been achieved ([23] at 107), the central authorities have relayed that they intend to conduct a review to establish what an appropriate model for a foreign national only prison would be, and that this would include discussion of resettlement and reoffending reduction. Steps were also put in place at the local level: the Head of Resettlement has been tasked with leading a team to develop a reducing reoffending strategy to reflect the needs of the prison population [23].

In addition to reactive measures, the anticipation of an inspectorate's visit can also result in proactive change intended to bring operations and procedures into line with contemporary best practice and international standards. For example, at Kongsvinger prison, management and staff prepared for a possible S'OM visit in advance by reviewing previous reports and recommendations made at other prisons and making necessary changes.

However, it is clear that the mandate and methodology of a particular oversight body may result in the disapplication of rehabilitation (and the consequences for prisoners, prison officers, society and the prison estate) being overlooked. Even bodies that have the same international obligations, such as NPMs established pursuant to UNOPCAT, have a different focus. Accordingly the comprehensiveness of their review will vary. This may result in discriminatory treatment that violates international treaty imperatives and undermines international and regional penal policy slipping under the radar.

\section{Conclusion}

Despite the unequivocal message in international and regional standards that prison should prepare prisoners for life after release, recent state practice has resulted in public and deliberate movements away from the duty to facilitate the rehabilitation and reintegration of foreign national prisoners. In particular, political imperatives and populist demands have resulted in the disapplication of the usual principled approach to punishment in foreign national only facilities. In these institutions, penal process for foreign offenders has become characterised by 'segregation and expulsion' ([4] at 2).

Residency based penal policy focuses on identifying members and controlling and excluding non-members. It does not address criminogenic needs or achieve human rights or penological objectives for punishment. Contemporary practice may therefore represent a significant macro-level obstacle to the successful implementation of the micro-level changes proposed by international penal standards. In a climate of hostility towards foreigners and the securitisation of migration, international standards, alone, may be insufficient to tackle the over-representation of foreigners in detention and a 
removal-focused approach to their penal management. Practice threatens to overshadow, and simultaneously, undermine attempts to improve the penal process for foreign prisoners and their chances of successful reintegration. This is why it is imperative that independent oversight bodies enforce such standards.

This paper has explored the role oversight bodies can and should play in upholding rehabilitation as the foundational objective for prison management in foreign national only prisons.

Overall, there appeared to be openness at an institutional level to discussions about change with oversight bodies and even a proactive stance taken to prepare for possible future inspections. In this way, it could be argued that the establishment and strengthening of the relationship of control over prisons ensured by international bodies has contributed to the shaping of prison policies and the creation of an efficient and transparent system for monitoring of human rights. However, it was clear that the value of such oversight was very dependent on the methodology and mandate of the particular oversight body. Where rehabilitation was a distinct head of assessment and clear recommendations were made for required remedies, oversight seemed to be an effective catalyst for change. Where this was not the case, it was clear that there was a danger that the disapplication of rehabilitation in foreign prisoner only facilities could slip under the radar.

For this particular category of rights-holders - prisoners without leave to remain - the panopticon based on monitoring of penal and prison policies did not seem to be inverted. In other words, in relation to rehabilitation, the supervision exerted by oversight bodies created pursuant to international obligations did not seem to be influenced by complaints from prisoners and NGOs. This vulnerable group often feel they do not have a voice. Moreover, their real energy is focused on resisting removal rather than campaigning for the re-introduction of rehabilitation and reintegration support. NGO pressure is also not present for this purpose. In this instance, the most vocal proponents for change were the staff and management at foreign national only facilities who have had to adapt the regime content without strategic support or resources.

It is crucial that international and regional oversight mechanisms rely on international treaty and soft law standards to insist on the reinstatement of rehabilitation at such facilities and to prevent its disapplication in other facilities.

Rather than try to reverse the march towards the creation of quasi-removal centres within the prison estate, expansion is planned. Ter Apel prison will expand to house all pre-trial detainees without leave to remain making it the sole facility in the country for such offenders. Expansion is also planned at Kongsvinger Prison. In 2015, HMP Peterborough was assigned as a unit for female prisoners liable for deportation or removal from the United Kingdom.

Scholars are increasingly asking how "deportability" shapes how foreign-national prisoners "do time" [24]. It is clear that when deportation becomes the dominant political and practical function, there seems to be a correlating subordination or removal of rehabilitation and resettlement functions ([12] at 9, 11). However, the fact that an individual will not be reintegrated into the detaining State's society does not negate State responsibility to provide reintegrative support. In addition to non-discrimination based arguments, there is growing academic and judicial discussion surrounding the recognition of an implicit right to rehabilitation for prisoners [25]. It is therefore imperative that international and regional oversight bodies remind State and prison authorities of their duty to facilitate the rehabilitation and reintegration of all prisoners 
(whatever their immigration status may be) - even if the detail of its implementation has changed.

Open Access This article is distributed under the terms of the Creative Commons Attribution 4.0 International License (http://creativecommons.org/licenses/by/4.0/), which permits unrestricted use, distribution, and reproduction in any medium, provided you give appropriate credit to the original author(s) and the source, provide a link to the Creative Commons license, and indicate if changes were made.

\section{References}

1. Ugelvik, T. (2014). The incarceration of foreigners in European prisons. In S. Pickering \& J. Hams (Eds.), The Routledge handbook on crime and international migration (pp. 107-120). London: Routledge.

2. Banks, J. (2011). Foreign National Prisoners in the UK: Explanations and implications. The Howard Journal of Criminal Justice, 50(2), 184-198.

3. Wacquant, L. (2006). Penalization, Depoliticization, racialization: On the over-incarceration of immigrants in the European Union. In S. Armstrong \& L. McAra (Eds.), Perspectives on punishment: The contours of control (pp. 83-100). Oxford: Clarendon Press.

4. Fekete, L., \& Webber, F. (2010). Foreign nationals, enemy penology and the criminal justice system. Race \& Class, 51(4), 1-25.

5. Cornelisse, G. (2010). Immigration detention and human rights: Rethinking territorial sovereignty. The Netherlands: Martin Nijhoff Publishers.

6. Schuster, L. (2005). A sledgehammer to crack a nut: Deportation, detention and dispersal in Europe. Social Policy and Administration, 39(6), 606-621.

7. Bosworth, M. (2012). Subjectivity and identity in detention: Punishment and society in a global age. Theoretical Criminology, 16(2), 123-140.

8. Hasselberg, I. (2015). Balancing legitimacy, exceptionality and accountability: On foreign-national offenders' reluctance to engage in anti-deportation campaigns in the UK. Journal of Ethnic and Migration Studies, 41(4), 563-579.

9. Snacken, S. (2006). A reductionist penal policy and European human rights standards. European Journal on Criminal Policy and Research, 12, 143-164.

10. Kaufman, E. (2012). Finding foreigners: Race and the politics of memory in British prisons. Population, Space and Place, 18(6), 701-714.

11. Scott, D., \& Codd, H. (2010). Controversial issues in prison. Maidenhead: Open University Press.

12. Warr, J. (2015). The deprivation of certitude, legitimacy and hope: Foreign national prisoners and the pains of imprisonment. In Special issue of Criminology and Criminal Justice: Punishment, citizenship and identity: The incarceration of foreign nationals (pp. 1-18).

13. Slade, L. (2015). Foreign National Prisoners; Best practice in prison and resettlement. Available at http://www.wcmt.org.uk/sites/default/files/report-documents/Slade\%20L\%20Report\%202015\%20 FINAL_0.pdf.

14. The Parliamentary Ombudsman Norway. (2015). National Preventative Mechanism against torture and ill-treatment. Kongsvinger Prison: Visit Report - Summary and Recommendations.

15. HM Chief Inspector of Prisons (August 2015). Report of an unaccounced inspection of HMP Maidstone. Available online at https:/www.justiceinspectorates.gov.uk/hmiprisons/wpcontent/uploads/sites/4/2015 /12/Maidstone-web- 2015.pdf. Accessed 10 Jan 2017.

16. HM Chief Inspector of Prisons (January 2013). Report of an announced inspection of HMP Huntercombe. Available online at http://www.justiceinspectorates.gov.uk/prisons/wpcontent/uploads/sites/4/2014/03 /huntercombe-2013.pdf. Accessed 10 Jan 2017.

17. HM Inspector of Prisons (2013). Report of an announced inspection of HMP Huntercombe. March 2013.

18. Turnbull, S., \& Hasselberg, I. (2017). From prison to detention: The carceral trajectories of foreignnational prisoners in the UK. Punishment and Society, 19(2), 135-154.

19. HM Chief Inspector of Prisons (2015). Report on an unannounced inspection of HMP Maidstone. 8 Dec 2015.

20. Gröning, L. (2014). Education for foreign inmates in Norwegian prisons: A legal and humanitarian perspective. Bergen Journal of Criminal Law and Criminal Justice, 2(2), 164-188. 
21. De Ridder, S., Beyens, K., \& Snacken, S. (2012). Does reintegration need REHAB? Early release procedures for prisoners without a legal permit of residence in Belgium. European Journal of Probation, 4(3), 21-36.

22. Barnoux, M., \& Wood, J. (2013). The specific needs of foreign National Prisoners and the threat to their mental health from being imprisoned in a foreign country. Aggression and Violent Behaviour, 18(2), 240246.

23. Chief Inspectors Report (2016). Action plan following HMIP report on HMP Maidstone. Available online at https:/www.justiceinspectorates.gov.uk/hmiprisons/wp-content/uploads/sites/4/2015/12/HMPMaidstone-Action-Plan-2016.pdf. Accessed 10 Jan 2017.

24. Bosworth, B., Hasselberg, I., \& Turnbull, S. (2016). Punishment, citizenship and identity: An introduction. In Punishment, citizenship and identity: The incarceration of foreign nationals. Special issue of Criminology and Crime Justice, 16(3), 257-266.

25. Van Zyl Smit, D., \& Weatherby, P. (2014). Whole life sentences and the tide of European human rights jurisprudence: What is to be done? Human Rights Law Review, 14(1), 59-84. 